\title{
Anode-Initiated Polymerizations of Olefins and Tetrahydrofuran
}

\author{
Seiichi Nakahama, Keiichi Hashimoto, and Noboru Yamazaki \\ Tokyo Institute of Technology, \\ 12-1, 2-Chome, Ookayama, Meguro-ku, Tokyo 152, Japan.
}

(Received August 7, 1972)

\begin{abstract}
The electrolytic polymerization of methyl methacrylate (MMA), styrene and tetrahydrofuran (THF) at the anode was investigated by using $\left(\mathrm{C}_{4} \mathrm{H}_{9}\right)_{4} \mathrm{NClO}_{4}$ and $\left(\mathrm{C}_{4} \mathrm{H}_{9}\right)_{4} \mathrm{NPF}_{6}$ as supporting electrolytes. These polymerization reactions were affected by the supporting electrolyte, monomer, and solvent. In the polymerizations of MMA in bulk and of styrene in solutions of dichloroethane and nitrobenzene, a free-radical and a cationic mechanisms were assumed, respectively.

Addition of olefins, such as styrene and isobutene which could be oxidized at the anode, increased the current efficiency in the electrolytic polymerization of THF. Poly-THF produced electrolytically in the presence of diphenylethylene, stilbene, and $\alpha$-methylstyrene contained several units of these olefins in each polymer chain. Oxidation waves of diphenylethylene and stilbene were observed in THF solution by the oscillopolarographic measurement. It is considered that the electron transfer from these olefins to anode preferentially occurred to form carbonium ions, which initiated cationic polymerization of THF.
\end{abstract}

KEY WORDS Electrolytic Polymerization / Poly-THF / Initiation / Electron Transfer / Cationic Polymerization /

There have been several reports on electrolytically initiated polymerizations of vinyl monomers at the anode. Anodic polymerization can be classified into three groups: a free-radical polymerization and two types of cationic polymerizations initiated with proton and with carbonium ions produced by electron transfer from monomer to the anode.

(1) Anions of supporting electrolytes are discharged at the anode to form radical species, which initiate free-radical polymerizations. For instance, acetate ion was oxidized at platinum anode to produce $\mathrm{CH}_{3} \mathrm{COO}$. and/or $\mathrm{CH}_{3}$., which initiated the radical polymerization of methyl methacrylate. ${ }^{1}$

(2) Radical species formed by oxidation of electrolytes abstract a hydrogen atom from solvent or monomer to form proton which initiates cationic polymerization. Tetrafluoroborate ion, $\mathrm{BF}_{4}^{-}$, in sulpholane was electrolytically oxidized to produce a radical, $\mathrm{BF}_{4} \cdot$, which reacted with sulpholane to form hydrogen fluoride and boron trifluoride and the proton of hydrogen fluoride initiated cationic polymerization of styrene. ${ }^{2}$ When tetrahydrofuran (THF) solution of tetrabutylammonium perchlorate $\left(\mathrm{Bu}_{4} \mathrm{NClO}_{4}\right)$ was electrolyzed, perchlorate radical, $\mathrm{ClO}_{4} \cdot$, was formed and abstracted a hydrogen atom from a THF molecule to produce a proton, which initiated the polymerization of THF. ${ }^{3}$

(3) There are vinyl monomers, which were electrolytically oxidized at anode in preference to the supporting electrolyte and solvent. Actually, in polarographic measurements, $N$ vinylcarbazole, 2-vinylpyridine, styrene, and its derivatives were reported to give oxidation waves in $\mathrm{Et}_{4} \mathrm{NClO}_{4}$-acetonitrile solution. ${ }^{4}$ In these cases, electron transfer is assumed to occur preferentially from monomer to platinum anode to produce a carbonium ion, resulting in initiation of cationic polymerization. We term this reaction a direct electron-transfer initiation. However, the initiation mechanism through the electron-transfer process has been obscure. In order to actually reveal the direct electrontransfer initiation, the anodic potential should be controlled to avoid oxidation of the electrolyte and it is desirable to obtain the stoichiometric relationship between number of produced polymer and amount of current passed. 
This paper concerns with electro-initiated freeradical and cationic polymerizations at anode, and cationic living-polymerizations of THF in the presence of diphenylethylene, stilbene and $\alpha$-methylstyrene was carried out by controlledpotential electrolyses. In the last case, it was confirmed by using gel-permeation chromatographic (GPC) techniques that produced poly-THF had several units of diphenylethylene, stilbene and $\alpha$-methylstyrene in the polymer chains. This indicates that the direct electron transfer from diphenylethylene, stilbene and $\alpha$-methylstyrene to the anode occurs forming carbonium ions which initiate polymerization of THF. As compared with the $\mathrm{THF}-\mathrm{Bu}_{4} \mathrm{NClO}_{4}$ system, the higher current efficiency, which was observed in the THF-diphenylethylene- $-\mathrm{Bu}_{4} \mathrm{NPF}_{6}$ system, clarified the relationship between the number of produced polymer and amount of current passed.

\section{EXPERIMENTALS}

\section{Materials}

Tetra- $n$-butylammonium perchlorate $\left(\mathrm{Bu}_{4}-\right.$ $\mathrm{NClO}_{4}$ ) was synthesized from tetra- $n$-butylammonium iodide (TBAI) and sodium perchlorate and recrystallized from ethylacetate.

Tetra- $n$-butylammonium nitrate $\left(\mathrm{Bu}_{4} \mathrm{NNO}_{3}\right)$ was synthesized from TBAI and silver nitrate and recrystallized from benzene-ethylacetate.

Tetra- $n$-butylammonium hexafluorophosphate $\left(\mathrm{Bu}_{4} \mathrm{NPF}_{6}\right)$ was synthesized from TBAI and potassium hexafluorophosphate and recrystallized from ethylacetate.

All monomers used were dried with calcium hydride by stirring the slurry under vacuum for $24 \mathrm{hr}$ and distilled into the cell through a vacuum line.

\section{Electrolytic Polymerization}

Electrolysis was carried out in the glass cell as previously described. ${ }^{3}$ The cell containing a supporting electrolyte was dried under high vacuum $\left(<10^{-5} \mathrm{mmHg}\right)$ at room temperature for about $10 \mathrm{hr}$. Monomers were distilled on a vacuum line into the cell. During the electrolytic polymerization of vinyl monomers, anolyte and catholyte were separately stirred at room temperature. Thereafter, they were individually treated by methanol to isolate the polymer. Purified polymer was obtained by the freeze-

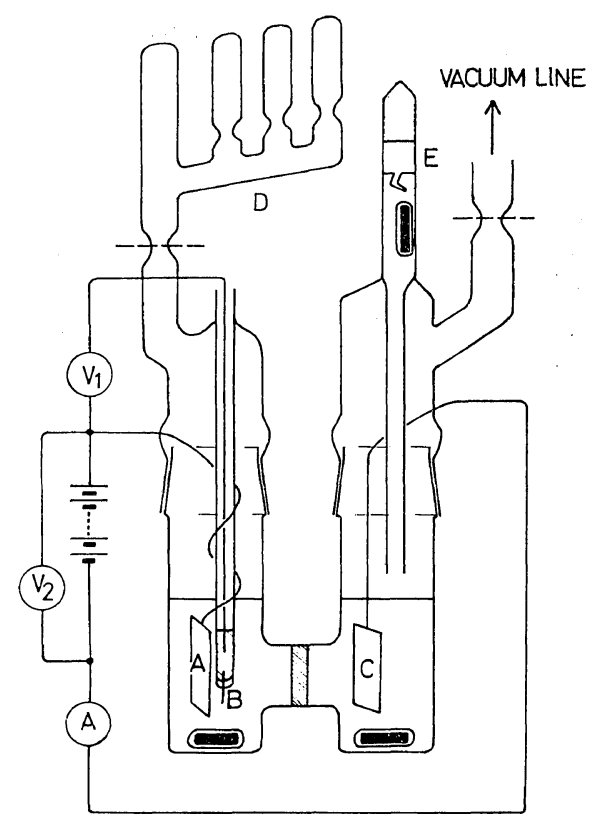

Figure 1. Electrolysis cell for living polymerization of THF: A, Pt anode; B, Pt auxiliary electrode; C, Pt cathode; D, ampoules for polymerization; E, diphenylethylene or $\alpha$-methylstyrene; $\mathrm{V}_{1}$ and $\mathrm{V}_{2}$, voltmeter (PM-18c, Toa Dempa Co.); A, ammeter.

drying method from benzene solution.

In the case of polymerization of THF, electrolysis was conducted at $0^{\circ} \mathrm{C}$ with $\mathrm{Bu}_{4} \mathrm{NClO}_{4}$ or $\mathrm{Bu}_{4} \mathrm{NPF}_{6}$ as a supporting electrolyte by using the apparatus as shown in Figure 1. The $i-V$ curves were measured for the diphenylethylene$\mathrm{THF}-\mathrm{Bu}_{4} \mathrm{NPF}_{6}$ and stilbene-THF- $\mathrm{Bu}_{4} \mathrm{NPF}_{6}$ systems by using an auxiliary platinum electrode, $\mathbf{B}$, which was adjacent to platinum anode, A, as shown in Figure 1. The potential difference between electrode $\mathrm{B}$ and $\mathrm{A}$ was regarded as a tentative anodic potential. During electrolysis, the preferential electron transfer from monomer to anode without decomposition of an electrolyte was achieved by manually controlling anodic potential at the potential shown by dashed lines in Figures 2 and 3. After electrolysis, anolyte was transferred into the glass ampoules D (Figure 1) which were then sealed off from the apparatus. The ampoules were kept at $0^{\circ} \mathrm{C}$ and $30^{\circ} \mathrm{C}$ for the required time. The polymer was obtained by precipitation with excess water and purified by the freeze-drying method from benzene solutions. 


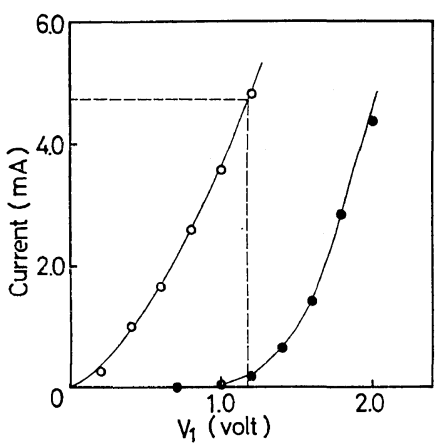

Figure 2. $i-V$ curves of diphenylethylene and $\mathrm{Bu}_{4} \mathrm{NPF}_{6}$ in THF: $\bigcirc$, with diphenylethylene; - without diphenylethylene; temp, $0^{\circ} \mathrm{C}$.

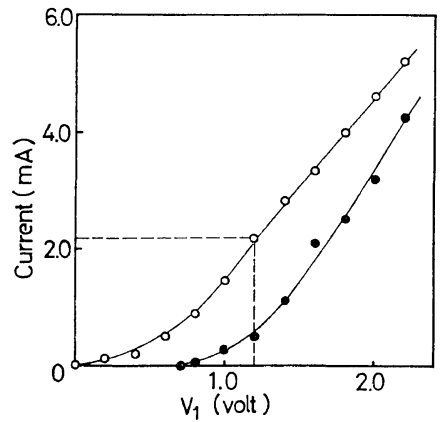

Figure 3. $i-V$ curves of stilbene and $\mathrm{Bu}_{4} \mathrm{NPF}_{6}$ in THF: $\bigcirc$, with stilbene; $\boldsymbol{O}$, without stilbene; temp, $0^{\circ} \mathrm{C}$.

The resulting poly-THF was dissolved in THF and was characterized by GPC; the molecular weight of the polymer was calculated by using the calibration curve which was made with the standard poly(ethylene oxide). Because it was quite difficult to remove residual diphenylethylene and stilbene from the low molecular weight polymer, the quantities of the olefins were determined by GPC and the yield of polymers were corrected. Optical density of the eluted fractions were measured at $250-260 \mathrm{~m} \mu$. The number of vinyl monomers attached to polyTHF was estimated by integrating the optical density-elution volume curve (Figure 6). As the molecular coefficients of vinyl monomer units, those of model compounds were adopted (Table I).

\section{Polarography}

Polarographic measurements were carried out at room temperature with $\mathrm{THF}$ solution of
Table I. Molar absorptivities of model compounds ${ }^{a}$

\begin{tabular}{|c|c|c|c|}
\hline $\begin{array}{c}\text { Vinyl monomer } \\
\text { unit }\end{array}$ & $\begin{array}{l}\text { Model } \\
\text { compound }\end{array}$ & $\underset{\mathrm{m} \mu}{\lambda \max }$ & $\varepsilon$ \\
\hline$-\mathrm{C}-\mathrm{CH}_{2} \mathrm{~J}$ & Diphenylethane & 262 & 620 \\
\hline$+\mathrm{CH}-\mathrm{CH}+$ & Bibenzyl & 262 & 515 \\
\hline$\pm \mathrm{C}-\mathrm{CH}_{2}+$ & Cumene & 253 & 165 \\
\hline
\end{tabular}

$\mathrm{Bu}_{4} \mathrm{NPF}_{6}$ as a supporting electrolyte by using a previously described polarograph cell ${ }^{5}$ and the Polarovision, PE-20 of Yanagimoto Mfg. Co., Ltd. Oxidation waves of diphenylethylene and stilbene were observed except for THF (Figure 8).

\section{RESULTS AND DISCUSSION}

As outined above, the radical species which are produced from supporting electrolytes by anodic oxidation, initiate radical or cationic polymerization. For such polymerizations, the experimental results and consideration of the reaction mechanism are described below.

Electro-Initiated Free-Radical Polymerization of

Methyl Methacrylate and Acrylonitrile

Homopolymerization of methyl methacrylate (MMA) and copolymerization of MMA with acrylonitrile (AN) in bulk occurred both in catholyte and in anolyte (Table II). The copolymer of MMA and AN obtained from catholyte seemed to be produced via anionic polymerization as was previously reported, ${ }^{6}$ since the copolymer was rich in AN. Since the molecular 
Table II. The electrolytic polymerization and copolymerization of MMA and AN in bulk ${ }^{\mathrm{a}}$

\begin{tabular}{|c|c|c|c|c|}
\hline \multirow[b]{2}{*}{ Monomer } & \multirow{2}{*}{$\begin{array}{l}\text { Amount of current } \\
\text { passed, } \mathrm{mF}\end{array}$} & \multirow{2}{*}{$\begin{array}{l}\text { Supproting } \\
\text { electrolyte }^{\mathrm{b}}\end{array}$} & \multicolumn{2}{|c|}{ Anodic polymer } \\
\hline & & & Yield, $\mathbf{g}(\%)$ & $\begin{array}{c}\text { Content of } \mathrm{AN} \\
\text { unit }^{\mathrm{c}}, \%\end{array}$ \\
\hline MMA & 0.5 & $\mathrm{Bu}_{4} \mathrm{NClO}_{4}$ & $1.7(6.3)$ & - \\
\hline MMA-AN & 12 & $\mathrm{Bu}_{4} \mathrm{NClO}_{4}$ & $0.25(0.9)$ & 34 \\
\hline MMA & 0.9 & $\mathrm{Bu}_{4} \mathrm{NNO}_{3}$ & $5.2(18)$ & - \\
\hline $\mathbf{M M A}-\mathrm{AN}$ & 0.4 & $\mathrm{Bu}_{4} \mathrm{NNO}_{3}$ & $0.87(3.2)$ & 34 \\
\hline MMA & 0.1 & $\mathrm{Bu}_{4} \mathrm{NPF}_{6}$ & $0.32(1.7)$ & - \\
\hline
\end{tabular}

a Monomer: MMA, $0.56 \mathrm{~mol}$ for homopolymerization; MMA, $0.36 \mathrm{~mol}$, AN, 0.36 mol for copolymerization. Electrolyzed at room temperature.

b Concentration, $0.1 \mathrm{M}$.

c Estimated from the nitrogen content of the copolymer.

weight of poly-MMA in catholyte was much higher than that of poly-MMA in anolyte, the propagation mechanisms were considered to be different. The anodic polymer seems to be formed by a free-radical polymerization because MMA is fairly unresponsive forwards cationic polymerization and anionic polymerization is unlikely in anodic compartment. The approximate $30-\%$ content of AN units in the copolymers of MMA and AN produced in anodic compartment also suggests a free-radical polymerization (Table II). As mentioned elsewhere, ${ }^{3}$ the perchlorate ion was oxidized to form perchlorate radical which decayed to related radicals as shown in eq 1 .

$$
\mathrm{ClO}_{4}^{-}-\mathrm{e} \longrightarrow \mathrm{ClO}_{4} \cdot \longrightarrow \mathrm{ClO}_{2} \cdot \text {, etc. }
$$

These radicals abstract a hydrogen atom from the monomer or add to monomer to yield a radical species which initiates radical polymerization (eq 2 and 3 ).<smiles>CCC(C=CC(=O)CCC(CC=O)C(=O)OC)C(=O)OC</smiles><smiles>COC(=O)CC(C)CC(=O)OC</smiles>

Nitrate radical would be also formed in the discharge of nitrate ion as well as the perchlorate ion (eq 4).

$$
\mathrm{NO}_{3}{ }^{-}-\mathrm{e} \longrightarrow \mathrm{NO}_{3} \text {. }
$$

Ross, et al., reported that nitrate ion was electrolytically oxidized in toluene to form nitrate radical, which abstracted a hydrogen atom from a toluene molecule to produce bibenzyl via radical coupling. ${ }^{7}$ These electro-initiated freeradical polymerizations of MMA an AN fall into the same category (1) as the polymerization initiated by oxidation of acetate ion. ${ }^{1}$

\section{Electro-Initiated Cationic Polymerization}

Tidswell and Doughty described the cationic polymerization of styrene which occurred when styrene was added to the anolyte, $\mathrm{Bu}_{4} \mathrm{NBF}_{4}$ sulpholane, which had been electrolyzed in the absence of monomer. ${ }^{2}$ It was suggested that the tetrafluoroborate ion was oxidized forming tetrafluoroborate radical, $\mathrm{BF}_{4} \cdot$, yielded hydrogen fluoride and boron trifluoride in sulpholane. Hydrogen fluoride and boron trifluoride with trace of water contained in the system initiated the cationic polymerization of styrene. In this

Table III. The polymerization of styrene with anolyte electrolyzed without monomer ${ }^{a}$

\begin{tabular}{lcc}
\hline Solvent & $\begin{array}{c}\text { Polymer yield, } \\
\%\end{array}$ & $\begin{array}{c}\text { Molecular weight } \\
\text { of polymer }\end{array}$ \\
\hline Dichloroethane & 75 & $4.4 \times 10^{3}$ \\
Nitrobenzene & 47 & $2.7 \times 10^{3}$
\end{tabular}

a After electrolysis, anolyte was transferred into an ampoule equipped with a break-seal. Thereafter styrene was added to anolyte through a breakseal. Conditions: amount of current passed, $0.51 \mathrm{mF}$; anolyte, $27 \mathrm{~m} l$; styrene, $3.1 \mathrm{~g}$; polymerization time, $1 \mathrm{hr}$; supporting electrolyte $\left(\mathrm{Bu}_{4} \mathrm{NClO}_{4}\right)$, $0.92 \mathrm{~g}$. 
Table IV. The electrolytic polymerization of styrene in anode*

\begin{tabular}{llcccc}
\hline Solvent & $\begin{array}{c}\text { Amount of } \\
\text { current, } \\
\text { mF }\end{array}$ & $\begin{array}{c}\text { Polymerization } \\
\text { timeb } \\
\text { min }\end{array}$ & $\begin{array}{c}\text { Polymer } \\
\text { yield } \\
\%\end{array}$ & $\begin{array}{c}\text { Molecular } \\
\text { weight of } \\
\text { polymer }\end{array}$ & $\begin{array}{c}\text { Number of } \\
\text { polymer, } \\
\text { mmol }\end{array}$ \\
\hline Dichloroethane & 0.56 & 0 & 47 & $3.0 \times 10^{3}$ & 0.49 \\
Nitrobenzene & 0.078 & 0 & 19 & 3.3 & 0.18 \\
& 0.078 & 155 & 42 & 2.9 & 0.48 \\
& 0.56 & 180 & 48 & 3.5 & 0.43 \\
& 0.099 & 80 & 47 & 3.8 & 0.38 \\
& 0.078 & 25 & 25 & 4.1 & 0.19 \\
& 0.063 & 50 & 35 & 4.6 & 0.24 \\
\hline
\end{tabular}

a Conditions: styrene, 3.1g; $\mathrm{Bu}_{4} \mathrm{NClO}_{4}, 0.92 \mathrm{~g}$; dichloroethane, $27 \mathrm{ml}$; nitrobenzene, $27 \mathrm{~m} l$ for each compartment. Electrolyzed at room temperature.

b Excluding the time for electrolysis.

c Polymer was obtained from anolyte. No polymer was found in catholyte.

investigation, as shown in Tables III and IV, electro-initiated cationic polymerization of styrene in nitrobenzene and dichloroethane solutions of $\mathrm{Bu}_{4} \mathrm{NClO}_{4}$ was examined. When styrene was added to the anolyte electrolyzed in the absence of monomer, polymerization occurred immediately. The polymerization was presumably initiated with perchloric acid which was produced by hydrogen abstraction of perchlorate radical from solvents as was described before. ${ }^{3}$ This polymerization was placed under the category (2), where anodic polymerization proceeded via radical-induced cationic mechanism.

As shown in Table IV, similar results were obtained when the $\mathrm{Bu}_{4} \mathrm{NClO}_{4}$-styrene-nitrobenzene and -dichloroethane systems were electrolyzed. Plotting $\ln \left([M]_{0} /[M]\right)$ against the second power of the reaction time yielded a straight line shown in Figure 4 as was reported by Funt and Blain. ${ }^{8}$ This kinetic relationship was derived on the assumptions: (a) the total number of active ends was proportional to the amount of current passed; (b) termination can be neglected in the polymerization. Although, according to Tidswell, ${ }^{2}$ polymerization of this system was regarded as being initiated by a proton, direct electron-transfer initiation might be also possible. This was supported by two obsarvations in the present study. First, styrene was observed to exhibit an oxidation wave in the polarographic measurement of this system. Second, when the $\mathrm{Bu}_{4} \mathrm{NClO}_{4}$ - MMA-styrene (molar ratio of monomers, 1:1) system was

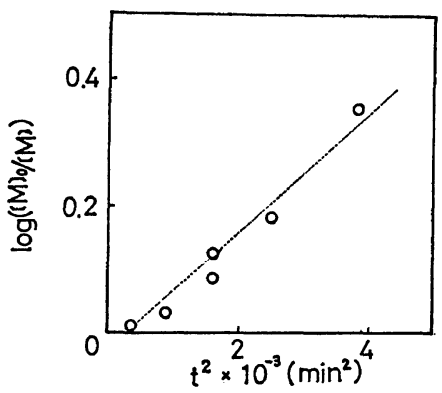

Figure 4. Electrolytic polymerization of styrene in nitrobenzene. Conditions are shown in Table IV.

electrolyzed, only a small amount of polystyrene was obtained from anolyte. This suggested that the anodic polymerization of styrene proceeded not via a radical mechanism, but via a cationic mechanism. If perchlorate radical produced by electrolytic oxidation provides both a proton and a radical species in this system as shown in eq $1-3$, they might initiate simultaneously cationic polymerization with proton and free-radical polymerization and as the result mixture of polystyrene and copolymer of styrene and MMA would be obtained. The fact that only polystyrene was obtained might indicate that the cationic polymerization of styrene was initiated with carbonium ion of styrene formed at the anode.

As shown in Table IV, the molecular weights of polymers produced were almost constant and the number of polymer depended predominantly 


\section{S. Nakahama, K. Hashimoto, and N. Yamazaki}

on the polymerization time. This indicates that chain-transfer reaction occurred repeatedly. There is no dependence of the number of polymer on the amount of current. Therefore, direct electron-transfer initiation could not be fully confirmed in this system.

Electro-Initiated Living-Polymerization of THF in the Presence of Diphenylethylene, Stilbene, and $\alpha$-Methylstyrene

Living polymerization of THF has been initiated by an electrolytic process at the anode. ${ }^{3}$ Although the current efficiency observed in the system $\left(\mathrm{Bu}_{4} \mathrm{NClO}-\mathrm{THF}\right)$ was as low as $20 \%$, a higher current efficiency was observed when isobutene or styrene was added to the electrolytic solution as shown in Figure 5. The enhance-

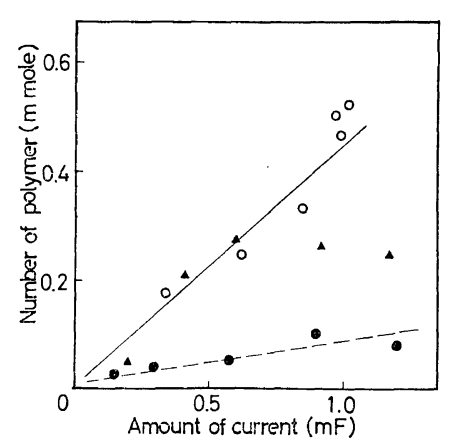

Figure 5. Number of poly-THF produced by electrolytic polymerization $v s$. amount of current passed: $\bullet$ THF; $\bigcirc$, THF-isobutene; $\Delta$, THFstyrene; supporting electrolyte, $\mathrm{Bu}_{4} \mathrm{NClO}_{4}$; electrolyzed at $0^{\circ} \mathrm{C}$ and polymerized at $30^{\circ} \mathrm{C}$. Anodic potential was not controlled. Current efficiency was calculated from the slope.

ment of current efficiency suggested that a different reaction was operative in the initiation reaction at anode; styrene and isobutene were oxidized at the anode to yield carbonium ions which effectively initiated the polymerization of THF. On the other hand, in the absence of the olefin, perchlorate radical initiated the polymer ization of THF with a low efficiency as described above. During electrolyses of the THF$\mathrm{Bu}_{4} \mathrm{NClO}_{4}$ - vinyl monomers system the anolyte became slightly brown, whereas in the absence of the vinyl monomer, the anolyte, $\mathrm{Bu}_{4} \mathrm{NClO}_{4}-\mathrm{THF}$, changed to dark brown. This might suggest that in the former case perchlorate ion was not oxidized to form perchlorate radical which produced dihydrofuran, ${ }^{3}$ because a colored polymer was formed from dihydrofuran as described by Dreyfuss, et al. ${ }^{9}$ These preliminary experiments implied that a direct electron-transfer initiation occurred in the THF- $\mathrm{Bu}_{4} \mathrm{NClO}_{4}$ - vinyl monomer system.

In order to substantiate the direct electrontransfer initiation, controlled-potential electrolyses of the $\mathrm{THF}-\mathrm{Bu}_{4} \mathrm{NPF}_{6}$-diphenylethylene, stilbene, and $\alpha$-methylstyrene systems were performed and the produced polymers were examined by using GPC techniques. As hexafluorophosphate ion was more stable to electrolytic oxidation than perchlorate ion, tetra$n$-butylammonium hexafluorophosphate was used as a supporting electrolyte instead of perchlorate. Polarographic measurements of diphenylethylene, stilbene and $\alpha$-methylstyrene were also carried out. In the course of electrolyses of the THF $\mathrm{Bu}_{4} \mathrm{NPF}_{6}$ - diphenylethylene system, the color of catholyte was initially blue and then changed to red. The red coloration of the catholyte was observed in the cases of the THF- $\mathrm{Bu}_{4} \mathrm{NPF}_{6}-$ stilbene and $-\alpha$-methylstyrene systems. This implied the formation of carbanions of the olefins in the cathode compartment. Migration of carbanion from cathode to anode compartment through the sintered glass could be neglected because termination reactions by carbanions were not observed. As shown in

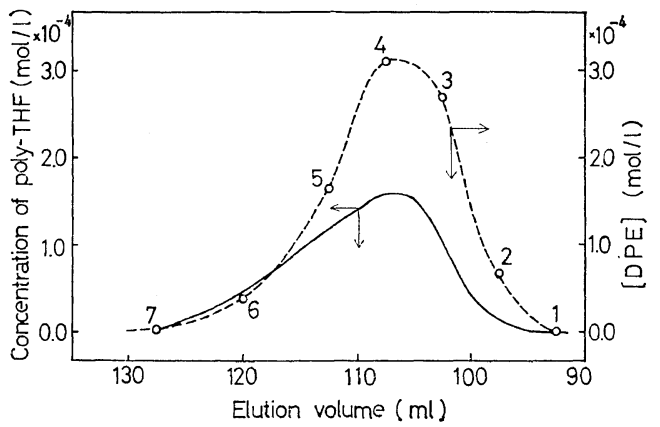

Figure 6. Gel-permeation chromatogram of polyTHF and concentration of diphenylethylene vs. elution volume: ——, concentration of polymer; -----, concentration of diphenylethylene; sample, D-11 (Table V); solvent, THF; flow rate, 1.0 $\mathrm{m} l / \mathrm{min}$. UV spectra of eluted fractions $(1-7)$ were shown in Figure 7. 


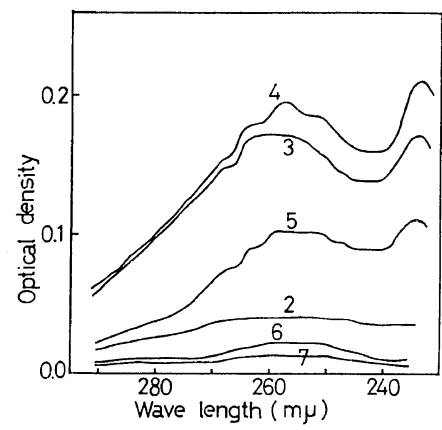

Figure 7. UV spectra of eluted fractions. Numbers 1-7 correspond to those shown in Figure 6 .

Figure 6, the peaks of the concentration curves of polymer and diphenylethylene unit $v s$. elution volume coincided in position with each other. Ultraviolet spectra of eluted fractions showed typical isolated-benzenoid fine-structure band as shown in Figure 7. Similar results were obtained by GPC and UV spectroscopy with respect to the $\mathrm{THF}-\mathrm{Bu}_{4} \mathrm{NPF}_{6}-$ stilbene and $-\alpha$-methylstyrene systems. These results indicate that diphenylethylene, stilbene and $\alpha$-methylstyrene are combined with poly-THF by covalent bond.

Oxidation waves of diphenylethylene and stilbene were observed at $1.7 \mathrm{~V}$ and $2.0 \mathrm{~V}$, respectively $v s$. platinum cathode as shown in Figure 8, whereas the oxidation wave of $\alpha$ methylstyrene could not be discriminated from that of hexafluorophosphate ion. Oxidation

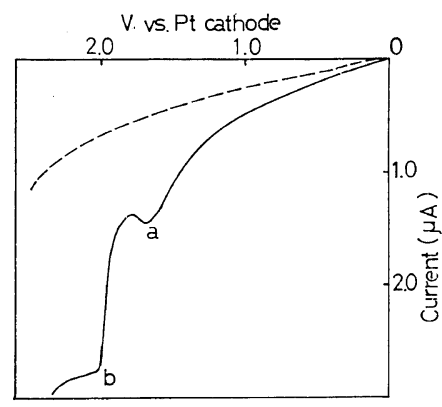

Figure 8. Oscillopolarograms of diphenylethylene and stilbene in THF: — oxidation waves of diphenylethylene (a) and stilbene (b) observed; ------, without monomer; supporting electrolyte, $\mathrm{Bu}_{4} \mathrm{NPF}_{6}$.

potential of $\alpha$-methylstyrene might be as noble as that of $\mathrm{PF}_{6}^{-}$. It was also observed in the $i-V$ curves of electrolytic solutions that stilbene was oxidized at more noble potential than diphenylethylene (Figures 2 and 3). As diphenylethylene, stilbene and $\alpha$-methylstyrene were not attacked by the propagating oxonium ion of poly-THF, an electron transfer was considered to occur from the olefin to the anode and subsequently the carbonium ion of the olefin initiated the polymerization of THF, producing polymer which had olefin units in its main chain (eq 5). By ultraviolet spectroscopic measurement, number of diphenylethylene,

Table V. The electro-initiated living-polymerization of THFdiphenylethylene- $\mathrm{Bu}_{4} \mathrm{NPF}_{6}$ system $^{\mathrm{a}}$

\begin{tabular}{|c|c|c|c|c|c|c|c|}
\hline No. & $\begin{array}{l}\text { Amount of } \\
\text { current, } \\
\mathrm{mF}\end{array}$ & $\begin{array}{l}\text { Current } \\
\text { density, } \\
\mathrm{mA} / \mathrm{cm}^{2}\end{array}$ & $\begin{array}{c}\text { Polymerization } \\
\text { time }^{\mathrm{b}}, \\
\mathrm{hr}\end{array}$ & $\begin{array}{l}\text { Yield of } \\
\text { polymer, } \\
\%\end{array}$ & $\begin{array}{l}\text { Molecular } \\
\text { weight of } \\
\text { polymer }^{\mathrm{c}}\end{array}$ & $\begin{array}{c}E_{\mathrm{ff}}, \mathrm{d} \\
\%\end{array}$ & $\frac{\mathrm{DPE}^{\mathrm{e}}}{\text { polymer }}$ \\
\hline D9-1 & & & 10.3 & 2.8 & $0.45 \times 10^{4}$ & 67 & 2.0 \\
\hline 2 & 0.16 & 1.8 & 20.8 & 8.4 & 1.3 & 69 & - \\
\hline 3 & 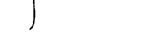 & & 25.3 & 12 & 1.7 & 76 & - \\
\hline D10 & 0.16 & 3.0 & 10.5 & 5.1 & 0.57 & 93 & 1.5 \\
\hline D11 & 0.17 & 0.25 & 9.3 & 8.2 & 1.2 & 67 & 1.3 \\
\hline$D 12^{\mathrm{f}}$ & 0.20 & 5.7 & 20.0 & 13.3 & 2.5 & 48 & 0.8 \\
\hline
\end{tabular}

a Electrolysis conditions: cell voltage, about $10 \mathrm{~V}$; supporting electrolyte $\left(\mathrm{Bu}_{4} \mathrm{NPF}_{6}\right), 0.1 \mathrm{M}$; THF, $40 \mathrm{~m} l$; diphenylethylene, $14 \mathrm{mmol}$ for each run. Electrolyzed and polymerized at $0^{\circ} \mathrm{C}$.

${ }^{b}$ Including the time for electrolysis.

- Estimated from the gel-permeation chromatogram.

a Current efficiency, $E_{\mathrm{f}}=$ [yield $/ M_{n} /$ amount of current] $\times 100$.

e Number of diphenylethylene units attached to one polymer.

${ }^{\prime}$ Cell voltage, $110 \mathrm{~V}$; anodic potential, $V_{1}=18.5 \mathrm{~V}$. 
Table VI. The electro-initiated living-polymerization of $\mathrm{THF}-$ stilbene- $\mathrm{Bu}_{4} \mathrm{NPF}_{6}$ system ${ }^{\mathrm{a}}$

\begin{tabular}{|c|c|c|c|c|c|c|c|}
\hline No. & $\begin{array}{c}\text { Amount of } \\
\text { current, } \\
\text { mF }\end{array}$ & $\begin{array}{l}\text { Current } \\
\text { density, } \\
\mathrm{mA} / \mathrm{cm}^{2}\end{array}$ & $\begin{array}{c}\text { Polymerization } \\
\text { time, } \\
\text { hr }\end{array}$ & $\begin{array}{l}\text { Yield of } \\
\text { polymer, } \\
\%\end{array}$ & $\begin{array}{l}\text { Molecular } \\
\text { weight of } \\
\text { polymer }\end{array}$ & $\begin{array}{c}E_{\mathrm{f}}, \\
\%\end{array}$ & $\frac{\text { Stilbene }}{\text { polymer }}$ \\
\hline S7-1 & & & 3.5 & 3.4 & $1.8 \times 10^{4}$ & 23 & 0.4 \\
\hline 2 & 0.14 & 0.53 & 4.5 & 3.6 & 2.2 & 20 & - \\
\hline 3 & ) & & 6.0 & 6.1 & 1.9 & 39 & - \\
\hline S8-1 & 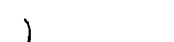 & & 8.0 & 1.4 & 2.0 & 7.8 & 1.2 \\
\hline 2 & 0.16 & 5.6 & 11.0 & 3.2 & 2.4 & 14 & - \\
\hline 3 & 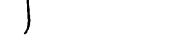 & ( & 14.0 & 5.5 & 2.5 & 24 & - \\
\hline
\end{tabular}

a Stilbene, $10 \mathrm{mmol}$. Other conditions are shown in Table V.

Table VII. The electro-initiated living-polymerization of $\mathrm{THF}-\alpha$-methylstyrene- $\mathrm{Bu}_{4} \mathrm{NPF}_{6}$ system $^{\mathrm{a}}$

\begin{tabular}{|c|c|c|c|c|c|c|c|c|}
\hline No. & $\begin{array}{c}\text { Amount of } \\
\text { current, } \\
\text { mF }\end{array}$ & $\begin{array}{l}\text { Current } \\
\text { density, } \\
\mathrm{mA} / \mathrm{cm}^{2}\end{array}$ & $\begin{array}{c}\alpha \text {-Methyl- } \\
\text { styrene, } \\
\text { mmol }\end{array}$ & $\begin{array}{c}\text { Polymeri- } \\
\text { zation } \\
\text { time, } \\
\text { hr }\end{array}$ & $\begin{array}{l}\text { Yield of } \\
\text { polymer, } \\
\%\end{array}$ & $\begin{array}{l}\text { Molecular } \\
\text { weight of } \\
\text { polymer }\end{array}$ & $\begin{array}{l}E_{\mathrm{f}}, \\
\%\end{array}$ & $\frac{\begin{array}{c}\alpha \text {-Methylsty- } \\
\text { rene }\end{array}}{\text { polymer }}$ \\
\hline M2-1 & & & & 6.5 & 2.7 & $1.1 \times 10^{4}$ & 21 & 1.7 \\
\hline 2 & 0.19 & 10 & 14.4 & 11.0 & 5.5 & 1.6 & 31 & - \\
\hline 3 & 1 & & & 14.0 & 7.1 & 2.1 & 30 & - \\
\hline M3-1 & 1 & & & 5.8 & 4.5 & 1.4 & 29 & 2.1 \\
\hline 2 & 0.18 & 0.51 & 15.4 & 10.3 & 7.6 & 1.8 & 40 & - \\
\hline 3 & J & & & 13.3 & 9.8 & 2.3 & 38 & - \\
\hline M4 & 0.15 & 0.16 & 40.6 & 10.5 & 4.5 & 1.3 & 42 & 2.4 \\
\hline M5 & 0.18 & 0.54 & 6.9 & 7.0 & 1.8 & 1.1 & 16 & 0.95 \\
\hline
\end{tabular}

a Conditions are shown in Table $\mathrm{V}$.

stilbene, and $\alpha$-methylstyrene units attached to poly-THF were estimated $1-2, \sim 1$, and $1-2.4$ unit per polymer molecule respectively (Tables V-VII). Although cationic propagation of these vinyl monomers hardly proceeded in THF, the number of $\alpha$-methylstyrene units attached to ploy-THF increased somewhat with increasing concentration of $\alpha$-methylstyrene (Table VII). This might be explicable if vinyl monomer is concentrated on the surface of anode by the electrostatic interaction and/or coupling reaction occurs between radical cations. Dreyfuss reported that in the polymerization of THF by trityl cation, hydride ion was abstracted from THF to yield proton, which polymerized THF. ${ }^{9}$ On the contrary, it was considered that in this system carbonium ions did not abstract a hydride ion, but attacked an oxygen atom of THF molecule resulting in oxonium ion. Though it is still ambiguous whether a THF molecule attacks a $\alpha$-carbon of diphenylethylene cation-radical or a $\beta$-carbon, a presumed mechanism of the initiation and propagation is proposed as follows

$$
\begin{aligned}
& \mathrm{CH}_{2}=\mathrm{C}\left(\mathrm{C}_{6} \mathrm{H}_{5}\right)_{2}-\mathrm{e}^{-} \longrightarrow \dot{\mathrm{C}} \mathrm{H}_{2}-\mathrm{C}^{+}\left(\mathrm{C}_{6} \mathrm{H}_{5}\right)_{2} \\
& {\left[\begin{array}{c}
\dot{\mathrm{C}} \mathrm{H}_{2}-\mathrm{C}^{+}\left(\mathrm{C}_{6} \mathrm{H}_{5}\right)_{2}+\mathrm{CH}_{2}=\mathrm{C}\left(\mathrm{C}_{6} \mathrm{H}_{5}\right)_{2} \\
\longrightarrow \dot{\mathrm{C}} \mathrm{H}_{2}-\mathrm{C}\left(\mathrm{C}_{6} \mathrm{H}_{5}\right)_{2}-\mathrm{CH}_{2} \mathrm{C}^{+}\left(\mathrm{C}_{6} \mathrm{H}_{5}\right)_{2}
\end{array}\right]} \\
& \stackrel{\mathrm{THF}}{\longrightarrow} \cdot \mathrm{CH}_{2}-\mathrm{C}\left(\mathrm{C}_{6} \mathrm{H}_{5}\right)_{2}-\mathrm{O}^{+} \\
& \stackrel{n \text { THF }}{\longrightarrow}(\mathrm{DPE})_{1-2}-(\mathrm{THF})_{n}-\mathrm{O}^{+}
\end{aligned}
$$

As shown in Tables V-VII, low current efficiency at low conversion of poly-THF was due to mechanical losses of low-molecularweight polymer. In contrast, a higher current efficiency, about $90 \%$, was observed especially in the diphenylethylene- $\mathrm{THF}-\mathrm{Bu}_{4} \mathrm{NPF}_{6}$ system. The enhancement of current efficiency was caused by less noble oxidation potential of diphenylethylene as compared with stilbene and $\alpha$-methylstyrene. If coupling of radical cations 
or two-electron transfer would occur at anode, transfer of two electrons might produce one polymer and, consequently, the current efficiency, (number of produced polymer)/(amount of current) $\times 100$, should be $50 \%$ at the most. In the case of the diphenylethylene-THF- $\mathrm{Bu}_{4} \mathrm{NPF}_{6}$ system, the observed efficiencies exceeded 50\% and especially the experimental value of D-10 was $93 \%$. This suggests that one-electron transfer occurs for diphenylethylene to yield one poly-THF. Consequently the coupling reaction between the free radicals which were produced by addition of THF molecule with diphenylethylene cation radicals (eq 5), could be excluded. The disproportionation was also ignored because of the lack of a $\beta$-proton in the radical. Presumably the radical abstracted a hydrogen atom from a THF molecule. In the cases of the stilbeneTHF- $-\mathrm{Bu}_{4} \mathrm{NPF}_{6}$ and $\alpha$-methylstyrene-THF$\mathrm{Bu}_{4} \mathrm{NPF}_{6}$ systems, as the found efficiencies were less than $50 \%$, coupling of radical cations and/or two-electron transfer also might occur. Current density seemed not to affect current efficiency as shown in Tables V-VII.

In conclusion, direct electron-transfer initiation in electro-initiated cationic polymerization was confirmed based on the following three observations. First, oxidation waves of diphenyl- ethylene and stilbene were observed in THF solution of $\mathrm{Bu}_{4} \mathrm{NPF}_{6}$. Second, poly-THF had several units of diphenylethylene, stilbene and $\alpha$-methylstyrene in their polymer chains. Third, high current efficiency probably is indicative of a one-electron transfer which produces one polymer.

\section{REFERENCES}

1. J. W. Breitenbach, Ch. Srna, and O.F. Olji, Makromol. Chem., 42, 171 (1960).

2. B. M. Tidswell and A. G. Doughty, Polymer, 12, 431 (1971).

3. S. Nakahama, S. Hino, and N. Yamazaki, Polymer J., 2, 56 (1971).

4. F. Sommer and J. W. Breitenbach, Preprint, International Symposium on Macromolecular Chemistry, Budapest, Vol. I, 1969, p 257.

5. S. Nakahama and N. Yamazaki, Polymer J. in press, (1972).

6. N. Yamazaki, I. Tanaka, and S. Nakahama, $J$. Macromol. Sci.-Chem., A2, 1121 (1968).

7. S. D. Ross, M. Finkelstein, and R.C. Petersen, J. Amer. Chem. Soc., 89, 4088 (1967).

8. B. L. Funt and T. J. Blain, J. Polym. Sci., Part A-1, 8, 3339 (1970).

9. M. P. Dreyfuss, J. C. Westfahl, and P. Dreyfuss, Macromolecules, 1, 437 (1968). 